\title{
Digestion of Mitochondrial DNA of Some Sudanese Camel Breeds Using Three Different Restriction Enzymes
}

\author{
M. Sulieman1,2, Yossra A. Malik¹, S. Sid Ahmed², A. A. Makkawi², Nahid Gornas ${ }^{1 *}$ \\ ${ }^{1}$ Unit of Molecular Biology and Immunology, Central Laboratory, Khartoum, Sudan \\ ${ }^{2}$ Faculty of Agricultural Studies, Sudan University of Science and Technology, Shambat, Sudan \\ Email: ngornas@hotmail.com
}

Received 5 April 2014; revised 17 May 2014; accepted 7 July 2014

Copyright (C) 2014 by authors and OALib.

This work is licensed under the Creative Commons Attribution International License (CC BY). http://creativecommons.org/licenses/by/4.0/

\section{(c) (i) Open Access}

\begin{abstract}
The purpose of this study was to estimate relationship between and within some Sudanese camel breeds (Kababeish, Shanabla and Nyalawei) by digestion of mitochondrial DNA using three different restriction enzymes. DNA was extracted from 45 blood samples of Sudanese camels (15 form each breed). Polymerase chain reaction was done using specific primers in order to amplify the D-Loop region. The PCR products were digested using 3 different restriction enzymes (tag1, hinf and scal). The products were run on agarose gel $2 \%$. The result of this study revealed differences between the three breeds according to digested and undigested samples. Tag1 did not cut any of the 45 samples of all breeds, while scal cut $4.4 \%$ of the Shanabla breed, $6.7 \%$ of Kababeish breed, but did not cut any of Nyalawei camels. The third restriction enzyme hinf cut all sample from Shanabla camels, and also cut $95.6 \%$ of Kababeish breed and also $95.6 \%$ of Nyalawei camels.
\end{abstract}

\section{Keywords}

Mitochondrial DNA, Camel, Sudan

Subject Areas: Genetics, Molecular Biology

\section{Introduction}

The genetic characterization of domestic animals is the first step in considering the sustainable management for conservation of a particular population. In the early 1990's, genotypic studies provided good information for animal diversity in the absence of qualified phenotypic assessment [1]. Conservation of vast animal genetic resources developed by farmers through the years is desirable to circumvent the loss of genetic diversity.

\footnotetext{
${ }^{*}$ Corresponding author.
}

How to cite this paper: Sulieman, M., Malik, Y.A., Sid Ahmed, S., Makkawi, A.A. and Gornas, N. (2014) Digestion of Mitochondrial DNA of Some Sudanese Camel Breeds Using Three Different Restriction Enzymes. Open Access Library Journal, 1: e667. http://dx.doi.org/10.4236/oalib.1100667 
In Africa, genetic diversity of farm animals is under threat due to diseases, conflicts and migration. Another factor that is equally perceived as a threat is uncontrolled crossbreeding of African breeds with exotic breeds. Most livestock improvement programmes in Africa have resorted to crossbreeding indigenous breeds with imported breeds or directly replacing the indigenous genotypes [2].

Among the domesticated populations, it is estimated that 1 to 2 breeds are lost every week according to the report of World Watch List of Domestic Animal Diversity [3]. However the documentation of these losses remains very poor.

Therefore, documentation of diversity of local genetic resources is needed to state new strategies for livestock conservation [4]. Livestock conservation activities include: documentation of existing genetic resources such as phenotypic characteristics, performance, cultural importance and genetic uniqueness [5]. Studies of genetic diversity in domestic animals are based on an evaluation of the genetic variation within breeds and genetic relationships among them [6].

Mitochondrial DNA (mtDNA) is inherited maternally [7], which means mtDNA haplotypes should be shared by all individuals within a maternal family line. The D-Loop region, which is the most variable part of mtDNA was very useful in the evolution studies of closely related species [8].

Useful information could be extracted from genetic studies. Also many molecular techniques have been developed to quantify genetic variations among breeds from allele frequency data. Combination of methods would provide sufficient information on difference between and within breeds [9].

RFLP or restriction enzyme polymorphism is a technique in which the DNA is isolated, cut using restriction enzymes, size fractioned on gels. The advantage of RFLP is that it can be used to screen large number of individuals without requiring complicated molecular techniques [10].

Sudan is second country in the world in camel's population. According to recent estimates of livestock, there are about 40 million heads of cattle, 50 million heads of sheep, 43 million heads of goat and 4.5 million heads of camel (18\% of the whole population in the world). Camels constitute about $26.3 \%$ of the numbers of camel in the Arab world [11]. Kordofan state is the leading one in camel population in the country.

The most famous owner camel's tribe in the western Sudan; includes Kababish, Hawaweer and Kawahla tribes. In Sudan, animals are usually named after the tribe names. North Kordofan state only has the highest camel population with more than one million heads, representing approximately $5 \%$ of the whole world camel population [12].

In the current study we aimed to estimate the genetic relationship between three different camel breeds, two of them share the area of pasture (Kababeish and Shanabla) at Kordofan state and another breed which inhabit a remote area (Nyalawei) in Darfur state.

\section{Materials and Methods}

Blood samples were collected from three different areas of camel tribes, Shanabla camel in Elrahad area, Kordofan state (Figure 1), Nyalawei camel in Darfur state (Figure 2), Kababeish camel in Kordofan state (Figure 3).

\section{DNA Extraction}

2 - $5 \mathrm{ml}$ of blood were collected from external jugular vein using sterile syringes and tubes containing EDTA as an anticoagulant. The samples were collected at random, irrespective of age and sex for each breed group. The DNA extraction was carried out at the Central Laboratory, Ministry of Science and Technology, Khartoum, Sudan. The technique used was the Modified Guanidine Chloride protocol.

\section{Oligonucleotide Primer Pair}

According to [13], the primer pair used to amplify mitochondrial D-Loop gene by polymerase chain reaction, were:

(Forward: 5-AGC CTT CTC TTC AGT CGC ACA C-3)

(Reverse: 5-GCC CAT GAA AGC TGT TGC T-3

Amplification of 208-bp DNA fragments was observed at the end of the reaction.

PCR Amplification of DNA Fragment: 


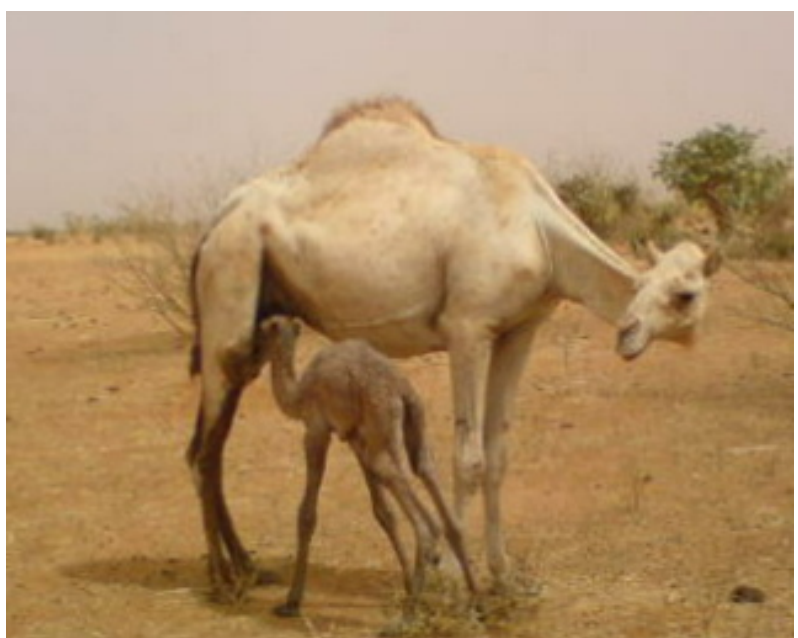

Figure 1. The picture of Shanabla camel which are found mainly in Elrahad area, Kordofan state.

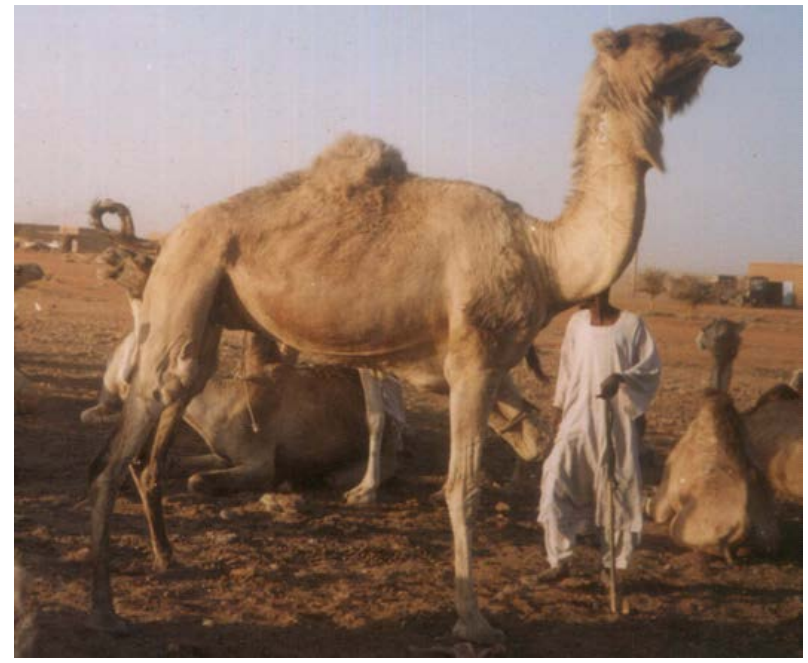

Figure 2. The picture of nyalawei camel which are mainly distributed in (darfur state).

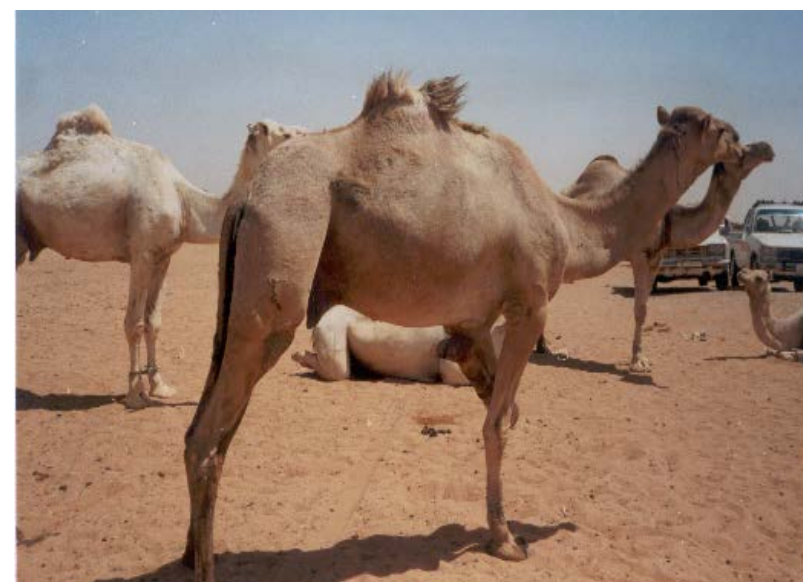

Figure 3. The picture of Kababeish camel which are found in (Kordofan state). 
The reaction mixture was prepared in a 25- $\mu$ l PCR tube (Master Mix (iNtRoN Biotechnology, Inc., Korea)), o.5- $\mu \mathrm{l}$ e of each primer (forward and reverse), $1 \mu \mathrm{l}$ of DNA template-distilled water 23- $\mu$ l. The PCR conditions programmed on master cycler gradient thermocycler (Eppendorf, Germany) were as follows: initial denaturation at $94^{\circ} \mathrm{C}$ for $5 \mathrm{~min}$ followed by 35 cycles of denaturation at $91^{\circ} \mathrm{C}$ for $1 \mathrm{~min}$, annealing at 54 for $1 \mathrm{~min}$, and extension at $72^{\circ} \mathrm{C}$ for $1.5 \min$ then, final extension Was done at $72^{\circ} \mathrm{C}$ for 10 min the PCR product was Kept at $-20^{\circ} \mathrm{C}$ for further analysis.

\section{Analysis of PCR-Amplified DNA Fragments}

Agarose gel electrophoresis was used for analysis of PCR products. The mixture was heated until the agarose is completely dissolved. Then, $1.5 \mu \mathrm{l}(0.2 \%)$ of ethidium bromide solution was added as a gel visualizing agent and mixed thoroughly. The electrophoresis was done for $50 \mathrm{~min}$ at $120 \mathrm{~V}$. The PCR product was finally visualized using gel documentation system.

\section{Digestion of -Amplified DNA Fragments with Restriction Enzymes (Tag1, Hinf and Scal)}

Restriction digestion assay was performed at a final volume of $20 \mu \mathrm{l}$ by mixing 0.5 units of Restriction enzyme with $1 \mu \mathrm{l}$ of the PCR product. The mixture was incubated over night at $37^{\circ} \mathrm{C}$. Then, the digested DNA

Fragments were run on $2 \%$ agarose gel for 50 minutes at $120 \mathrm{v}$.

\section{Results and Discussion}

The diversity of Sudanese camel based on the digestion of D-Loop gene region of the mitochondrial DNA revealed the following results: the amplified PCR product (208 bp), was subjected for digestion using three different endonuclease enzymes (tag1, hinf \& scal).

The Sudan is one of the biggest countries concerning animal numbers especially in camels. Large areas in Western Sudan are inhabited by nomadic tribes who believe in camels as animal of choice. Those tribes move all the year from place to another looking for water and better pasture.

Nomadic pastoralists have a global food producing strategy depending on the management of herd animals for meat, milk, wool, skin, manure and transport. Nomadic Pastoralism is practiced in different climates and environments with daily movements and seasonal migration. Nomadic societies have field armed men to protect their livestock and their people. The products of the herd animals are the most important resources, although the use of other resources including plants, hunted animals and market stuff are not excluded.

Mobility throughout the regions and the resulting precipitation differences are evaluated by pastoralists. In east Africa, different animals are taken to specific regions throughout the year that correspond to the seasonal pattern of precipitation. Pastoralists have maps drawn out in their minds mark out the value of specific environments at different times of the year. Shared information is vital for creating knowledge through the networks of linked societies.

Pastoralism which depends on movements of livestock is economically the most efficient, securing the livelihood for large sections and lessening the ecological impact on the environment, even the return per area of fuzzy nature is higher than well defined property rights or commercial ranching [14].

In the current study we aimed to start looking deep in the genetic relationships and genetic diversity between Sudanese camel breeds under nomadic system.

The first restriction enzyme (tag1) did not find a restriction site to cut in the three species (Table 1 and Figure 4), although the same enzyme was nominated in former Egyptian study, as the enzyme of choice to detect the camel meat from different animal meats [13], it seems that they were talking about Egyptian breeds and this may be a genetic marker for them, also this result raised a question about the difference between camel breeds in Arabic world.

The second restriction enzyme (scal1) cut small number in two breeds and left the rest of samples uncut (Figure 5 and Table 2), this result revealed that the genetic diversity started to differentiate with in breed maybe as a result of cross breeding with outsider animals. These two breeds were Kababeish and Shanabla, those two tribes share adjacent areas in Kordofan region and it make sense that they share genetic back ground in their animals. 
Table 1. Tag 1 enzyme digestion.

\begin{tabular}{cccc}
\hline population & No. of animals & cut & Uncut \\
\hline Kababeish & 15 & $0(0 \%-)$ & $(100 \%) 15$ \\
Shanabla & 15 & $0(0 \%-)$ & $(100 \%) 15$ \\
nayalawie & 15 & $0(0 \%-)$ & $(100 \%) 15$ \\
\hline
\end{tabular}

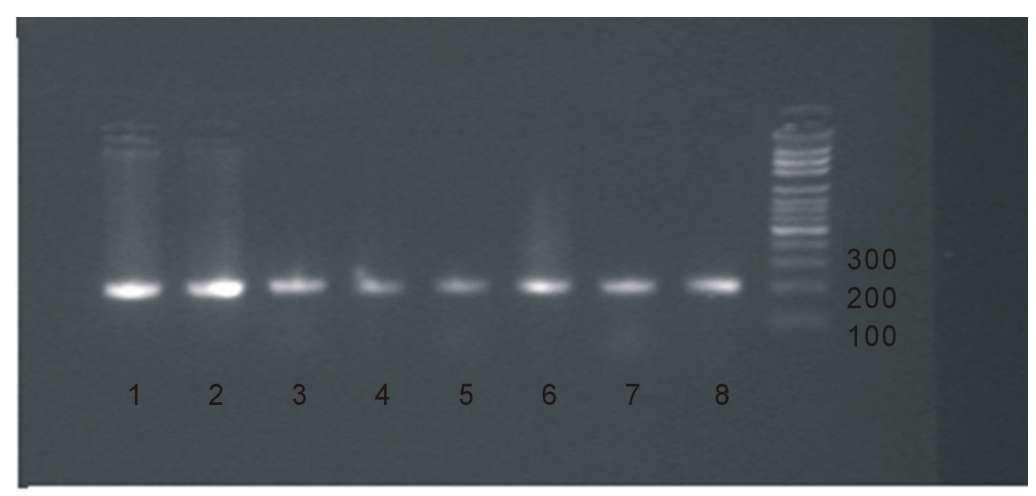

Tag 1 which cut 208 bp In all samples with no reaction

\section{it confirmed PCR size}

Figure 4. The results of 208 bp PCR product digestion using tag1 restriction enzyme.

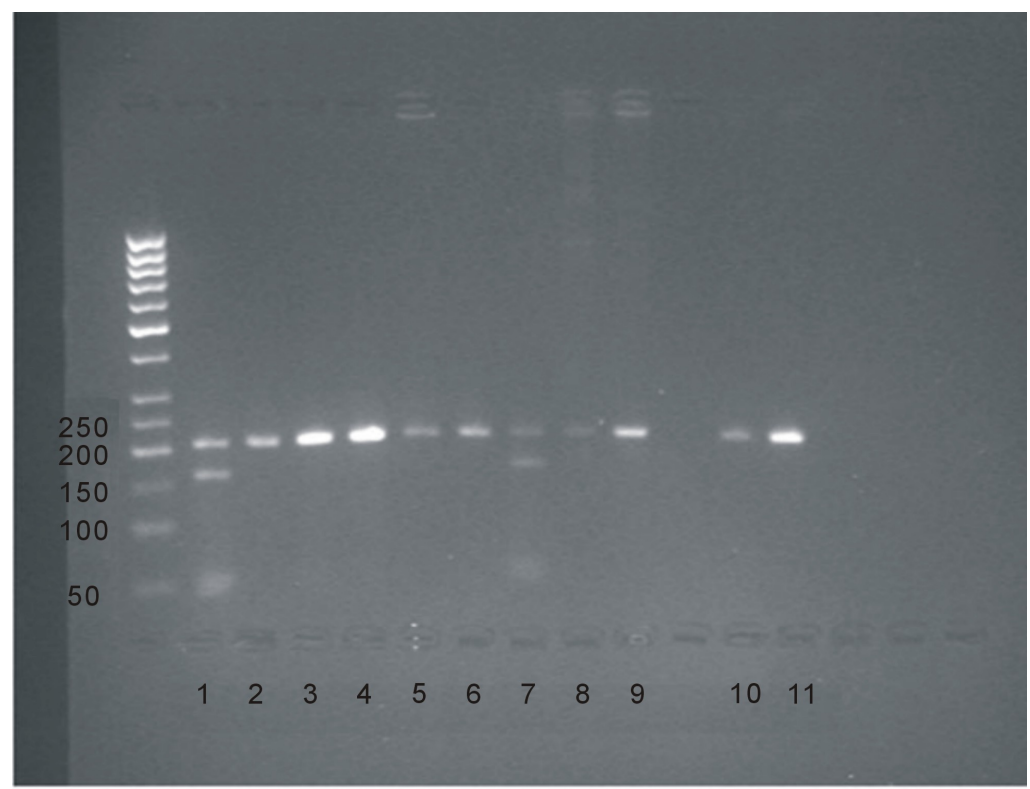

Scal enzyme which cut No (1 and 7) $208 \mathrm{bp}$ in to $50 \mathrm{bp}$ and $158 \mathrm{bp}$

Figure 5. The digestion of the 208 bp PCR product using Scal restriction enzyme.

Strikingly, the third enzyme (hinf1) which has the high number of cuts found a restriction site in Kababeish and in Shanabla and also in the genome of Nyalawei camels (Table 3 and Figure 6). The first two are owned by 
Table 2. Scal enzyme digestion.

\begin{tabular}{cccc}
\hline population & No .of animals & cut & Uncut \\
Kababeish & 15 & $2(6.7 \%)$ & $13(93.3 \%)$ \\
Shanabla & 15 & $1(4.4 \%)$ & $14(95.6 \%)$ \\
Nayalawie & 15 & $0(0.0 \%)$ & $15(100.0 \%)$ \\
\hline
\end{tabular}

Table 3. The same PCR product when digested with hinf.

\begin{tabular}{cccc}
\hline population & No .of animals & Cut & Uncut \\
\hline Kababeish & 15 & $14(95.6 \%)$ & $1(4.4 \%)$ \\
Shanabla & 15 & $15(100 \%)$ & $0(0 \%)$ \\
Nayalawie & 15 & $14(95.6 \%)$ & $1(4.4 \%)$ \\
\hline
\end{tabular}

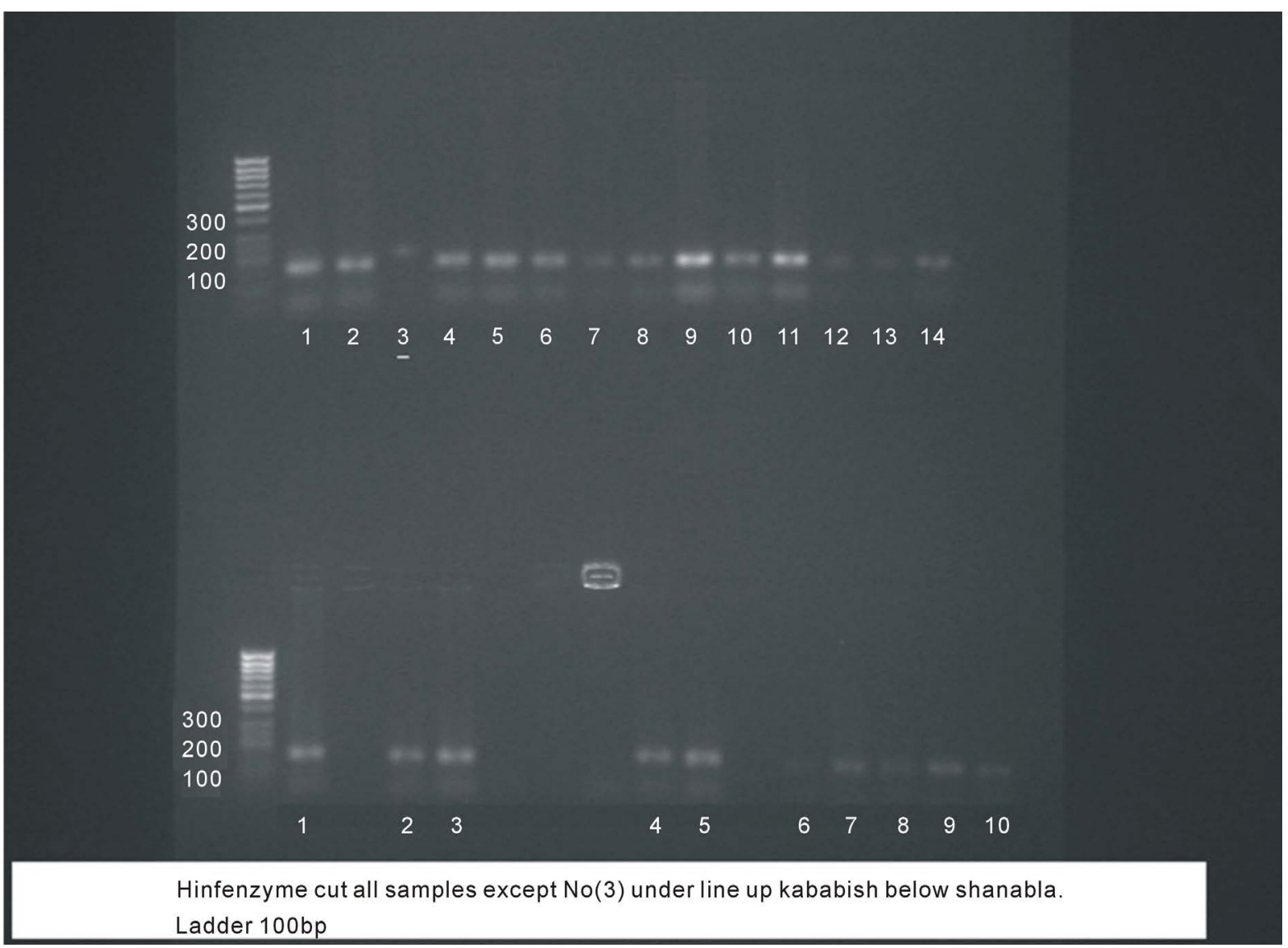

Figure 6. Digestion of 208 bp PCR product using hinf restriction enzyme, upper line are Kababeish breed, under are Shanabla breed samples.

tribes which inhabit two adjacent areas, but the Nyalawei breed inhabit different region far in the west, this may be due to the direct impact of Darfur conflicts which enforced the tribe which own Nyalawie camel to move to the borders of Kordofan area, and this resulted in cross breeding with camels in that area.

Another observation is that restriction enzymes could find restriction sites in most of the samples of some breeds, that means the diversity of those breeds and shared genetic background which may be due to the shared nomadic knowledge about traditional breeding, that they follow safe ways of selection for the male to ensure the conservation of the colour and general phenotypic features of the animals which belong to their tribes. 


\section{Conclusion}

This study was the first study in Sudan concerning Mitochondrial DNA of camel. The small number samples included in this study made it difficult to extract concrete results, but it highlighted some dark areas, which led us to recommend further studies on Sudanese camel genomic and mitochondrial DNA and the impact of nomadic system on the genetic diversity of Sudanese Livestock.

\section{Acknowledgments}

The authors want to thank all the staff members at the Molecular biology and Immunology unit-Central Laboratory-Ministry of Science and Technology for their assistance and hospitality.

\section{References}

[1] Toro, M.A., Fernandez, J. and Caballero, A. (2006) Scientific Basis for Policies in Conservation of Farm Animal Genetic Resources. Proceedings of 8th World Congress on Genetics Applied to Livestock Production, Belo Horizonte, United Nations, Rome.

[2] Wollny, C.B.A. (2003) The Need to Conserve Farm Genetic Resource in Africa: Should Policy Makers Be Concerned? Ecological Genomics, 45, 341-351.

[3] FAO (2003) World Watch List for Domestic Animal Diversity, 3rd Edition, Food and Agriculture Organization, Rome.

[4] Hanotte, O. and Jianlin, H. (2005) Genetic Characterization of Livestock Populations and Its Use in Conservation Decision Making. Proceedings of Workshop on the Role of Biotechnology, Turin, 5-7 March 2005, 131-136.

[5] Alvarez, I., Traore, A., Tamboura, H.H., Kabore, A., Royo, L.J., Fernandez, I., Ouédraogo-Sanou, G., Sawadogo, L. and Goyache, F. (2009) Microsatellite Analysis Characterizes Burkina Faso as a Genetic Contact Zone between Sahelian and Djallonke Sheep. Animal Biotechnology, 20, 47-57. http://dx.doi.org/10.1080/10495390902786926

[6] Tapio, I., Tapio, M., Grislis, Z., Holm, L.E., Jeppsson, S., Kantanen, J., Miceikiene, I., Olsaker, I., Viinalass, H. and Eythorsdottir, E. (2005) Unfolding of Population Structure in Baltic Sheep Breeds Using Microsatellite Analysis. Heredity, 94, 448-456. http://dx.doi.org/10.1038/sj.hdy.6800640

[7] Hutchinson, C.A., Newbold, J.E., Potter, S.S. and Hall, E.M. (1974) Maternal Inheritance of Mammalian Mitochondrial DNA. Nature, 251, 536-538. http://dx.doi.org/10.1038/251536a0

[8] Ishida, N., Hasegawa, T., Takeda, K., Sakagami, M., Onishi, A., Inumaru, S., Kamtsu, M. and Mukoyama, H. (1994) Polymorphic Sequence in the D-Loop Region of the Equine Mitochondrial DNA. Animal Genetics, 25, 215-221. http://dx.doi.org/10.1111/j.1365-2052.1994.tb00196.x

[9] Alvarez, I., Gutierrez, J.P., Royo, L. J., Fernandez, I., Gomez, E., Arranz, J.J. and Goyache, F. (2005) Testing the Usefulness of the Molecular Coancestory Information to Assess Genetic Relationships in Livestock Using a Set of Spanish Sheep Breeds. Animal Science, 83, 737-744.

[10] Aquadro, C.F., Jennings, R.M., Bland, M.M., Laurie, C.C. and Langley, C.H. (1992) Patterns of Naturally Occurring Restriction Map Variation, Dopa Decaoxylase Activity Variation and Linkage Disequilibrium in DdC Gene Region of Drosphilia melongaster. Genetics of American Society, 132, 443-452.

[11] M.A.R. (2008) Ministry of Animal Resources. Department of Statistic and Information, Khartoum-Sudan.

[12] Statistical Bulletin for Animal Production (2005) Sudan Issue, 14.

[13] El-Morshedy, A.E.-D., El-Daly, E.-S.A., El-Atabany, A.I. and Tharwat, A.E. (2011) Identification of Adulteration with Camel Meat Using Polymerase Chain Reaction Assay. Journal of American Sciences, 7, 339-343.

[14] Moran, E.F. (2006) People and Nature: An Introduction to Human Ecological Relations. Blackwell Publishing, Malden, 51-52. 